\title{
Demonstration of an Osteoblast Defect in Two Cases of Human Malignant Osteopetrosis

\author{
Correction of the Phenotype after Bone Marrow Transplant
}

Daniel Lajeunesse, Lambert Busque, Patrice Ménard, Michèle G. Brunette, and Yvette Bonny

Centre de Recherche Guy Bernier et Unité de Greffe de Moëlle Osseuse, Hôpital Maisonneuve-Rosemont, Montréal, Québec, Canada, H1T $2 M 4$

\begin{abstract}
Osteopetrosis is an inherited disorder characterized by bone sclerosis due to reduced bone resorption. Here we report that human osteopetrotic osteoblast-like $(\mathrm{Ob})$ cells express a defective phenotype in primary cultures in vitro, and that bone marrow transplant (BMT) corrects osteoblast function. DNA analysis at polymorphic short-tandem repeat loci from donor, recipient, and primary Ob-like cells pre-BMT and 2 yr post-BMT revealed that $\mathrm{Ob}$ were still of recipient origin post-BMT. Osteopetrotic Ob-like cells obtained preBMT showed normal and abnormal $1,25(\mathrm{OH})_{2} \mathrm{D}_{3}$-induced alkaline phosphatase (ALPase) and osteocalcin production, respectively, and failed to produce macrophage colonystimulating factor (M-CSF) in response to IL-1 $\alpha$ and TNF- $\alpha$. These parameters were all normalized in primary Ob-like cells prepared 2 yr post-BMT. X-linked clonality analysis at the human androgen receptor (HUMARA) locus revealed that osteoblasts showed a polyclonal and an oligoclonal derivation pre- and post-BMT respectively, indicating that a limited number of progenitor reconstituted this population. Because osteoblasts were still of recipient origin post-BMT, this suggests that functional osteoclasts, due to the replacement of hematopoeitic cells, provided a local microenvironment in vivo triggering the differentiation and/or recruitment of a limited number of functional osteoblasts. (J. Clin. Invest. 1996. 98:1835-1842.) Key words: human osteopetrosis - osteoblast defect - clonality assay - macrophage colonystimulating factor $\cdot$ bone marrow transplant
\end{abstract}

\section{Introduction}

Osteopetrosis is an inherited disorder characterized by bone sclerosis due to reduced bone resorption. Marrow cavities fail to develop and result in extramedullary hematopoiesis, leading to severe hematologic abnormalities associated with optic atrophy, deafness, and mental retardation. Heterogeneous clinical, biochemical, and histologic features suggest that the disease is multigenic $(1,2)$, and can be classified into five groups

Address correspondence to Daniel Lajeunesse, Ph.D., Unité des Maladies Rhumatismales, Centre de Recherche L.C. Simard, Pavillon J.A. DeSève, Hôpital Notre-Dame, 1560 Rue Sherbrooke Est, Montréal, Québec, Canada, H2L 4M1; Phone: 514-876-0914 or 0907; FAX: 514-876-5979.

Received for publication 20 February 1996 and accepted in revised form 15 July 1996.

J. Clin. Invest.

(C) The American Society for Clinical Investigation, Inc. 0021-9738/96/10/1835/08 \$2.00

Volume 98, Number 8, October 1996, 1835-1842 according to severity. In humans, only one form has been clearly identified and is due to carbonic anhydrase II deficiency (3), preventing acid release, which is essential for bone mineral dissolution.

The defect in hematopoeitic stem cells can sometimes be cured by bone marrow transplant $(\mathrm{BMT})^{1}$ in children $(4,5)$. BMT also corrects the anomaly in some animal models $(6,7)$. In other types of osteopetrosis, BMT is unsuccessful and it seems that the defect lies principally in the bone marrow microenvironment. Elevated plasma 1,25-dihydroxyvitamin $\mathrm{D}_{3}$ $\left(1,25(\mathrm{OH})_{2} \mathrm{D}_{3}\right)$ concentrations in animal mutants $(8)$ and in several osteopetrotic children $(2,9)$, together with the observation of in vivo resistance to pharmacologic doses of $1,25(\mathrm{OH})_{2} \mathrm{D}_{3}(9)$, suggested that osteoclasts or their progenitor cells may be resistant to the hormone. In children exhibiting the osteopetrotic mutation, disturbed mineral metabolism, including low plasma calcium (10-13) and phosphorus levels (11-13), and increased parathyroid gland activity $(11,12)$ have been observed.

Bone formation may be abnormal in mutant rat models due to altered expression of genes involved in osteoblast differentiation $(14,15)$. Indeed, bone osteocalcin is greatly reduced in two mutant rat models (op/op and tl/tl), coexistent with a reduced number and activity of osteoclasts (16). Considering that the extracellular matrix in bone plays a key role in cell recruitment and differentiation (17), this observation suggests that osteocalcin abnormalities may be a contributing factor in osteopetrosis. Osteocalcin levels have been reported normal or low in osteopetrotic children (2). However, in a subgroup of six children, the activity of osteoblasts, evaluated by circulating alkaline phosphatase and osteocalcin, and osteoblast number measured by bone histology, were not increased, despite hyperparathyroidism, suggesting a resistance to PTH or defective osteoblasts (2).

A local bone marrow microenvironment defect may also be present in the op/op mutant mouse model (18) because: $(a)$ BMT fails to correct osteopetrosis; $(b)$ they have a drastically reduced number of resident peritoneal cells and blood monocytes (19); and (c) they have relatively few active osteoclasts in bones. Macrophage colony stimulation factor (M-CSF), which is necessary for the growth and differentiation of hematopoietic cells (20), is produced by osteoblast-like cells (21-23), cooperates with other factors such as interleukin-3 (IL-3) and -1 (IL-1) in the formation of osteoclasts, and may also be impaired in these animals (24).

We prepared primary osteoblast-like cell cultures from bone biopsies of two osteopetrotic patients to determine if an

1. Abbreviations used in this paper: BMT, bone marrow transplant; HUMARA, human androgenreceptor. 
osteoblast defect was part of the expression of this disease. The production of alkaline phosphatase, osteocalcin, and M-CSF by these osteopetrotic cells was aberrant pre-BMT. This situation was corrected in one patient from whom we could prepare primary cultures $2 \mathrm{yr}$ post-BMT. Taken together, this suggests that an osteoblast defect is present in human osteopetrosis, a situation that is corrected by BMT.

\section{Methods}

Patients and clinical parameters. The osteopetrotic patients were 6-mo- (EC) and 12-mo- (MG) old girls referred for bone marrow transplantation. The diagnosis was confirmed by histologic examination, which showed numerous inactive osteoclasts in bone slices that were unable to create resorption cavities. Bone marrow transplantations were performed using a chemotherapy-based preparative regimen which consisted of Busulfan $(4 \mathrm{mg} / \mathrm{kg})$ for $4 \mathrm{~d}$ and Cyclophosphamide $(50 \mathrm{mg} / \mathrm{kg})$ for $4 \mathrm{~d}$. Graft versus host disease $(\mathrm{GVH})$ prophylaxis consisted of adjusted dose cysclosporine A (CSA) and short course methotrexate. MG had an allogeneic matched unrelated transplant, and EC a related transplantation from her HLA-compatible sibling. Seric parameters $\left(1,25(\mathrm{OH})_{2} \mathrm{D}_{3}\right.$, alkaline phosphatase, calcium, and osteocalcin) were evaluated three times a week. Alkaline phosphatase and calcemia were determined within our clinical facilities, whereas $1,25(\mathrm{OH})_{2} \mathrm{D}_{3}$ and osteocalcin were determined by RIA. Normal individuals undergoing surgery or investigation for bone marrow transplant with no signs of metabolic diseases were also used as controls for the preparation of primary bone cell cultures. One was a 12-yr-old boy (G12), and the others were two adults (HBC and JR).

Primary bone cell cultures. Human primary bone cell cultures were prepared as previously described (25) from bone biopsies of normal individuals, pre-BMT for EC and MG, and $2 \mathrm{yr}$ post-BMT for EC (bone marrow transplant was successful for patient MG as assessed at the 3-mo follow-up, but MG died 6 mo post-BMT of pulmonary restriction). Briefly, bone explants were washed free of blood, and trabecular bone was cut out of surrounding cortical bone and minced in $2 \mathrm{~mm}^{2}$ pieces. These pieces were digested three times with collagenase type I (1 mg/ml, Clostridium histolyticum; Sigma Chemical Co., St. Louis, MO) for 20, 20, and 40 min, washed three times in media HAMF12/Dubecco's Modified Eagle's Medium (DMEM) 1:1, then placed in $100 \mathrm{~mm}$ plastic culture dishes (Nunc) and covered with HAMF12/DMEM $+20 \%$ fetal bovine serum (FBS) $+1 \%$ InsulinTransferrin-Selenium (ITS) mix (Sigma Chemical Co.). The medium was replaced every $2 \mathrm{~d}$ until cells were observed ( 5 to $8 \mathrm{~d}$ ). The medium was then replaced by HAMF12/DMEM with $10 \%$ FBS $+50 \mathrm{ug} / \mathrm{ml}$ ascorbic acid and changed twice a week. Cells reached confluence within 21 to $28 \mathrm{~d}$ in culture. At confluence, cells were passaged once at a ratio of 1:6 and grown in $35 \mathrm{~mm}$ dishes (Nunc). The cells were left to recover for $2 \mathrm{~d}$ before assays.

DNA isolation. Several samples were obtained to document the origin of the osteoblast-like cells population post BMT in patient EC: (a) cells from buccal mucosa (recipient); (b) peripheral blood cells 2 yr after BMT (donor cells); (c) osteoblast-like cells prior to transplantation; and $(d)$ osteoblast-like cells $2 \mathrm{yr}$ post-BMT. DNA isolation was done as follows: $3-5 \mathrm{ml}$ of peripheral blood was lysed with Triton X-100 (Sigma Chemical Co.) lysis solution (0.32 M Sucrose; $10 \mathrm{mM}$ Tris, $\mathrm{pH} 7.5 ; 5 \mathrm{mM} \mathrm{MgCl}$; $1 \%$ Triton X-100), digested with proteinase $\mathrm{K}$ in SDS buffer (Proteinase $\mathrm{K} 2 \mathrm{mg} / \mathrm{ml}, 5 \%$ SDS) at $37^{\circ} \mathrm{C}$ for $24 \mathrm{~h}$, then DNA was extracted with phenol, phenol/chloroform, and chloroform, precipitated with 2 vol of absolute ethanol and 0.1 vol of $3 \mathrm{M}$ sodium acetate, and resuspended in Tris-EDTA (TE) buffer. The buccal cells and osteoblast-like cells were processed as for the peripheral blood with the omission of the Triton X-100 lysis.

Genetic identification of osteoblasts by short tandem repeat polymorphic loci analysis. DNA form the recipient (buccal cells), donor (peripheral blood cells $2 \mathrm{yr}$ post-BMT), osteoblast-like cells prior and
2 yr post-BMT were amplified at three short tandem repeat (STR) polymorphic loci in a multiplex reaction (GenePrint ${ }^{\mathrm{TM}}$ STR System; Promega Corp., Madison, WI). The polymorphic loci included CSF1PO at 5q33.3-34, TH01 at 11p15.5, and TPOX at 2p13. Amplification was conducted according to the manufacturer's instruction. Amplified products were run on a $5 \%$ denaturing polyacrylamide gel for $90 \mathrm{~min}$ at $60 \mathrm{~W}$. Gels were stained with silver nitrate (DNA silver staining system; Promega Corp.) according to the manufacturer's instructions. A picture of the film was obtained using the APS film (Promega Corp.).

HUMARA clonality assay. X-inactivation clonality assay was conducted at the human androgen receptor locus (HUMARA) as previously described (26) with minor modifications (27). Briefly, genomic DNA was precut by mixing sample DNA (100 ng-1 $\mu \mathrm{g}$ in $2 \mu \mathrm{l})$ with HpaII (1 $\mu$ l, high concentration, $40 \mathrm{U} / \mathrm{ul})$, RsaI ( $0.5 \mathrm{ul}$, high concentration, $40 \mathrm{U} / \mathrm{ul})$, L buffer ( $2 \mu \mathrm{l}$; Boehringer Mannheim Biochemicals, Indianapolis, IN) and $\mathrm{H}_{2} \mathrm{O}(14.5 \mu \mathrm{l})$. An autocontrol was prepared in the same way except that HpaII was omitted from the mix. Samples were incubated at $37^{\circ} \mathrm{C}$ overnight, and heat inactivated at $95^{\circ} \mathrm{C}$ for $4 \mathrm{~min}$ prior to amplification. $2 \mu \mathrm{l}$ of digested DNA were added to $23 \mu \mathrm{l}$ of a PCR mix containing buffer $(10 \times: 500 \mathrm{mM} \mathrm{NaCl}, 100 \mathrm{mM}$ Tris$\mathrm{HCl}, \mathrm{pH} 8.2 ; 15 \mathrm{mM} \mathrm{MgCl}, 0.1 \%$ gelatin); dNTPs (200 $\mu \mathrm{M}$ each); primer HUMARA I: 5'-GCTGTGAAGGTTGCTGTTCCTCAT-3' and primer HUMARA II: 5'-TCCAGAATCTGTTCCAGAGCGTGC-3' (12.5 pmol each); DMSO (1.0 $\mu$ l, Sigma Chemical Co.); $\gamma^{-32} \mathrm{P}$ end-labeled HUMARA I primer $(1.25 \mathrm{pmol})$, Taq polymerase (0.5 U, Perkin Elmer-Cetus Instruments, Emeryville, CA); and $\mathrm{H}_{2} \mathrm{O}$ to final volume of $23 \mu \mathrm{l}$. Samples were amplified on a programmable thermal cycler (MJ Research, Inc., Watertown, MA); initial DNA denaturation at $94^{\circ} \mathrm{C}$ for $3 \mathrm{~min}$, then 28 cycles starting with $94^{\circ} \mathrm{C}$ for $45 \mathrm{~s}$, $60^{\circ} \mathrm{C}$ for $30 \mathrm{~s}$, and $72^{\circ} \mathrm{C}$ for $30 \mathrm{~s}$. At the end of amplification $12.5 \mu \mathrm{l}$ of formamide loading buffer ( $95 \%$ formamide, $20 \mathrm{mM}$ EDTA, $0.05 \%$ bromophenol blue, $0.05 \%$ xylene cyanol) was added to each sample, and samples were denatured at $95^{\circ} \mathrm{C}$ for $3 \mathrm{~min}$ and chilled rapidly. Amplified PCR products $(8-10 \mu \mathrm{l})$ were electrophoresed on a $4 \%$ acrylamide-urea-formamide denaturing gel at $60 \mathrm{~W}$ for $\sim 3 \mathrm{~h}$.

Quantitation of alleles. The allele ratio was defined as the ratio between the two X-linked alleles in a given sample. The corrected ratio (CR) was defined as the allele ratio of the pre-cut sample divided by the allele ratio of the non-precut sample of the same specimen. This ratio compensates for potential preferential amplification of one of the two alleles. Gels were exposed to high performance autoradiography film overnight at $-80^{\circ} \mathrm{C}$. The developed film was scanned on a LKB Bromma Ultroscan XL laser densitometer (Uppsala, Sweden) and the ratios between the two $\mathrm{X}$-linked alleles were measured using Gel Scan XL software (LKB Bromma).

Osteocalcin and cellular alkaline phosphatase determination. Osteocalcin (OC) release was measured in HAMF12/DMEM (1:1) media containing $2 \%$ charcoal-stripped FBS, $1 \%$ PS, and $50 \mu \mathrm{g} / \mathrm{ml}$ ascorbic acid. Osteocalcin was determined by a RIA (Biomedical Technologies, Inc., Stoughton, MA) as previously described $(25,28)$. Alkaline phosphatase (ALPase) activity was determined as the release of $p$-nitrophenol hydrolyzed from $p$-nitrophenyl phosphate $(12,5 \mathrm{mM}$ final $)$ at $37^{\circ} \mathrm{C}$ for $30 \mathrm{~min}$ after solubilizing the cells in $\mathrm{AL}$ Pase buffer (100 mM glycine, $1 \mathrm{mM} \mathrm{MgCl}_{2}, 1 \mathrm{mM} \mathrm{ZnCl}, 1 \%$ Triton $\mathrm{X}-100, \mathrm{pH} 10.5)$ with agitation for $60 \mathrm{~min}$ at $5^{\circ} \mathrm{C}$. Alkaline phosphatase was determined immediately on aliquots. Protein determination was performed by the method of Lowry et al. (29).

Measurement of macrophage colony-stimulating factor. Confluent cells, plated on six wells/plate, were washed twice with PBS, pH 7.4, and covered with $1 \mathrm{ml}$ of HAMF12/DMEM (1:1) media containing $2 \%$ FBS, $50 \mu \mathrm{g} / \mathrm{ml}$ ascorbic acid, and $1 \mathrm{ng} / \mathrm{ml} \mathrm{IL-} 1 \alpha, 2 \mathrm{ng} / \mathrm{ml} \mathrm{TNF-} \alpha$, or the vehicle. After $72 \mathrm{~h}$ of incubation at $37^{\circ} \mathrm{C}$, the supernatant was recuperated. M-CSF was measured by a double-sandwich ELISA using a primary goat anti-human M-CSF antibody (R \& D Systems, Minneapolis, MN) for $2 \mathrm{~h}$ at $37^{\circ} \mathrm{C}$. Following an incubation with unknown samples or standards, a polyclonal rabbit anti-human M-CSF (Genzyme Corp., Markham, Ontario, Canada) was then added for $1 \mathrm{~h}$ at 
Table I. Serum Parameters of Osteopetrotic Patients Before Marrow Transplant

\begin{tabular}{lcc}
\hline & \multicolumn{2}{c}{ Osteopetrotic patients } \\
\cline { 2 - 3 } \multicolumn{1}{c}{ Parameter } & EC & MG \\
\hline $\mathrm{Pi}(\mathrm{mM})(1.23-1.62)$ & 0.59 & $0.7 \pm 0.08$ \\
$\mathrm{Ca}(\mathrm{mM})(2.26-2.73)$ & $2.17 \pm 0.06$ & $2.01 \pm 0.05$ \\
$1,25(\mathrm{OH})_{2} \mathrm{D}_{3}(\mathrm{pM})(29.4 \pm 13)$ & 63.4 & 613 \\
ALPase* $(\mathrm{U} / \mathrm{liter})(<300)$ & $1617 \pm 254$ & $947.5 \pm 55$ \\
Osteocalcin $(\mathrm{ng} / \mathrm{ml})(10-40)$ & $6.02 \pm 0.17$ & $39.2 \pm 8.6$ \\
\hline
\end{tabular}

Values are the mean \pm SEM of three or four determinations within $2 \mathrm{wk}$ from transplant. Values in parentheses are the normal range for the parameters evaluated.

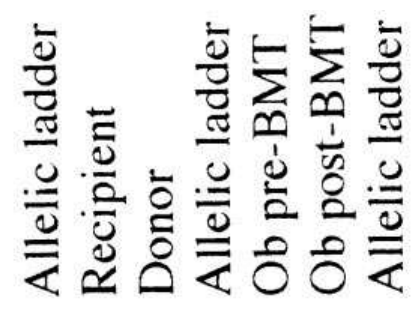

STR Loci

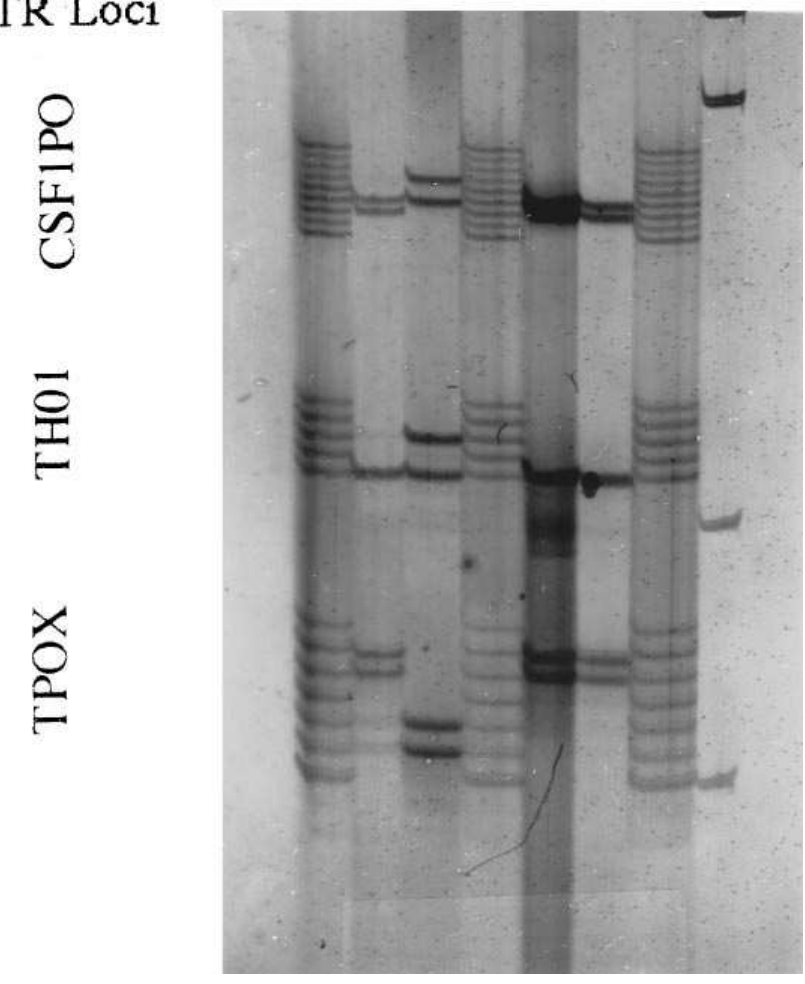

Figure 1. STR analysis of origin of osteoblast-like cells post-BMT. Multiplex STR analysis at the CSF1PO, THO1, and TPOX loci of recipient (buccal cells), bone marrow donor (peripheral blood $2 \mathrm{yr}$ post-BMT), osteoblast-like cells pre-BMT (Ob pre-BMT), and osteoblast-like cells $2 \mathrm{yr}$ post-BMT (Ob post-BMT). Genotype analysis of peripheral blood cells $2 \mathrm{yr}$ post-BMT reveals a completely different genotype than of the recipient. This reflects complete donor cell chimerism post-BMT. However, genotype analysis of osteoblast-like cells $2 \mathrm{yr}$ post-BMT is identical to recipient and to osteoblast-like cells pre-BMT. $37^{\circ} \mathrm{C}$. The detection of this second antibody was performed by the addition of a goat anti-rabbit antibody coupled to a peroxidase (Organon-Technika, Scarborough, Ontario, Canada), and the peroxidase activity was evaluated by the hydrolysis of $0.05 \%$ ABTS substrate (Organon-Technika) at $405 \mathrm{nM}$. The validation of the ELISA shows intraassay variations of $6 \%$ and interassay variations of $8 \%$.

Statistics. Values are expressed as the mean \pm SEM of $n$ separate determinations. Statistical differences were evaluated by analysis of variance in dose-response experiments and by two-tailed Student's $t$ tests. The statistical test performed is indicated in each case, and the number of experiments performed is indicated in the individual legends.

\section{Results}

Seric parameters. Before BMT, seric $1,25(\mathrm{OH})_{2} \mathrm{D}_{3}$ and alkaline phosphatase were very high in both osteopetrotic patients (Table I). These high levels of circulating $1,25(\mathrm{OH})_{2} \mathrm{D}_{3}$ were corrected by the intervention, and within 10 wk post-BMT, the seric levels were normalized for EC. Seric alkaline phosphatase had essentially the same behavior as seric $1,25(\mathrm{OH})_{2} \mathrm{D}_{3}$ and was corrected (adjusted for the age of the patient) by 8 wk post-BMT. Calcemia was low (Table I), and was further reduced prior to transplant possibly in part due to the very low calcium diet given to these patients. Regardless of the diet, the post-BMT calcemia raised and returned to normal values within 2 to $3 \mathrm{wk}$, indicating a progressive return to normal resorption. Phosphatemia was also low for both patients (Table I). Seric osteocalcin, an indicator of bone turnover, was strikingly low for one patient (EC) compared to normal patients in this age group, while it was normal for the second patient (MG) (Table I). This parameter was progressively corrected after BMT, but significant correction was noted only after 5 to $6 \mathrm{wk}$. By 6 wk post-BMT, osteocalcin ranged between 14 and $16 \mathrm{ng} / \mathrm{ml}$ for EC, which is in the low normal range of this age group.

Genetic origin of osteoblast-like cells post-BMT by PCR analysis of polymorphic STR loci. STR analysis at the c-fms protooncogene (CSF1PO), tyrosine hydroxylase (THO1), and thyroid peroxidase (TPOX) allowed complete distinction between the genotype of the recipient (buccal cells) and the bone marrow donor (peripheral blood, 2 yr posttransplant). The absence of recipient alleles post-BMT demonstrates complete chimerism of donor cells (Fig. 1). However, osteoblast-like cells obtained 2 yr post-BMT reveal the same genotype as the recipient and of the osteoblast-like cells obtained prior to transplant. Therefore, osteoblasts are still of recipient origin 2 yr post-BMT (Fig. 1).

Alkaline phosphatase and osteocalcin production by primary cell cultures. Primary bone cell cultures (normal, G12; and osteopetrotic patients, EC and MG) showed a gradual increase in alkaline phosphatase activity in response to increasing doses of $1,25(\mathrm{OH})_{2} \mathrm{D}_{3}$, although in the osteopetrotic cells the initial values in the absence of $1,25(\mathrm{OH})_{2} \mathrm{D}_{3}$ were variable and higher than the values from the normal cell culture. The dose-response to the hormonal treatment was however similar and parallel in all three cultures (Fig. 2). This increase in in vitro alkaline phosphatase activity may explain the high circulating levels of alkaline phosphatase, in osteopetrotic patients, which reflect the activity of osteoblasts. Normal bone cell cultures also produced osteocalcin in response to $1,25(\mathrm{OH})_{2} \mathrm{D}_{3}$ (about a 20-fold increase), while the osteopetrotic cultures responded much less to the hormonal treatment (a 2- to 3-fold 


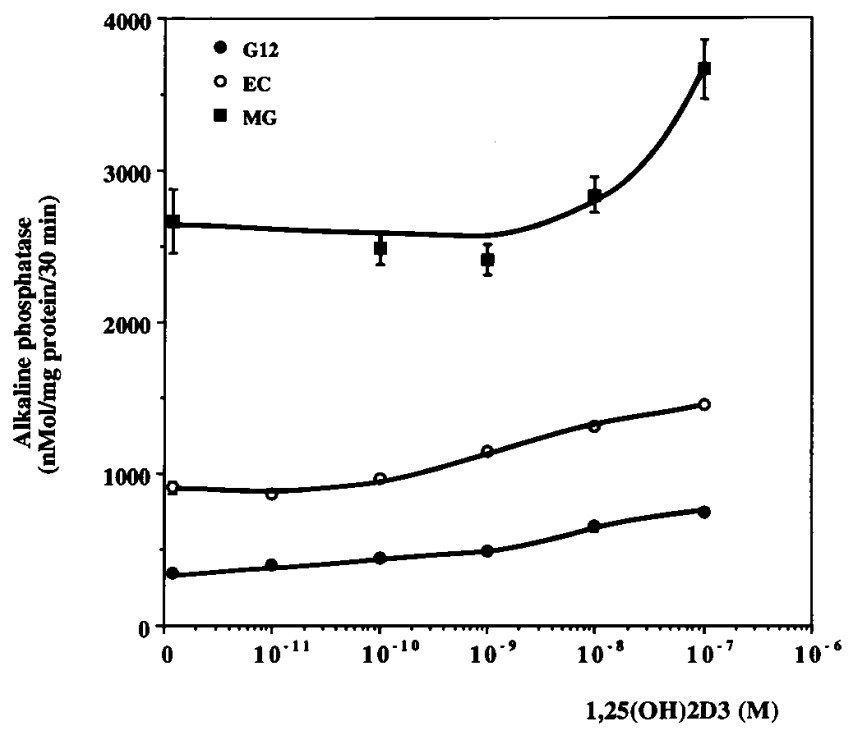

Figure 2. Cellular alkaline phosphatase in human primary bone cell cultures. Primary human bone cell cultures of a normal (G12) and two osteopetrotic patients (EC, MG) were treated with increasing doses of $1,25(\mathrm{OH})_{2} \mathrm{D}_{3}$ for $48 \mathrm{~h}$. At the end of this incubation, cellular alkaline phosphatase was determined in these cultures in quadruplicate dishes. The results show the mean \pm SEM of these assays. The dose-response to $1,25(\mathrm{OH})_{2} \mathrm{D}_{3}$ was significant within each cell culture by analysis of variance $(P<0.005)$.

increase, $P<0.001$ vs. normal cells, Fig. 3). Human parathyroid hormone fragment 1-34 (PTH, $100 \mathrm{nM})$ failed to inhibit osteocalcin secretion in these osteopetrotic cell cultures (not shown), in contrast to the situation generally observed in normal cells under these conditions (25).

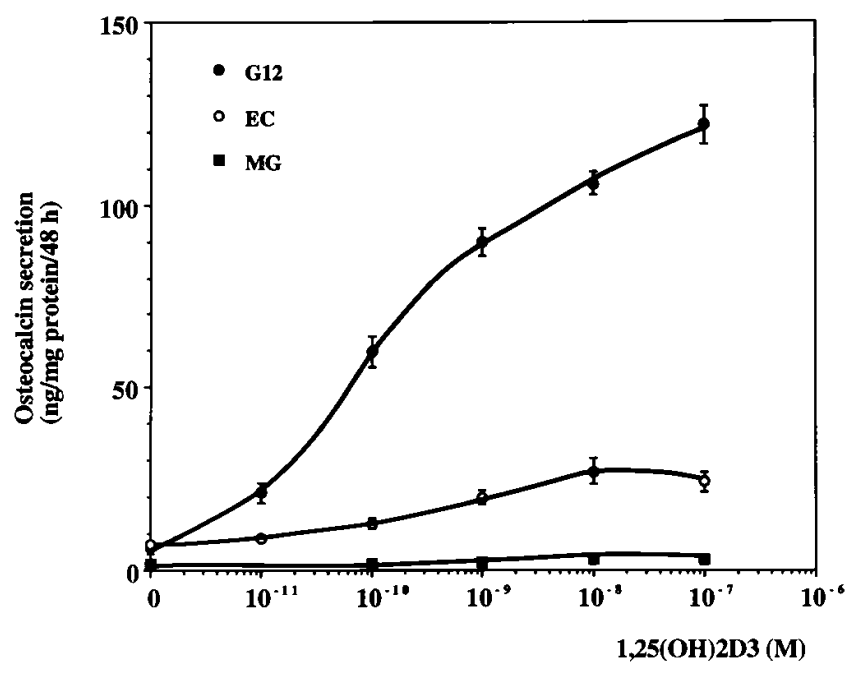

Figure 3. Secretion of osteocalcin by human primary bone cell cultures. The supernatant of the cells treated with increasing doses of $1,25(\mathrm{OH})_{2} \mathrm{D}_{3}$ and used for alkaline phosphatase determination in Fig. 1 were used for the determination of osteocalcin release. Osteocalcin was determined by RIA, and the results show the mean \pm SEM of quadruplicate dishes for each condition. The secretion of osteocalcin was greatly reduced in the bone cell cultures of the osteopetrotic patients as compared to the normal patient at all doses tested $(P<0.001$ by analysis of variance).

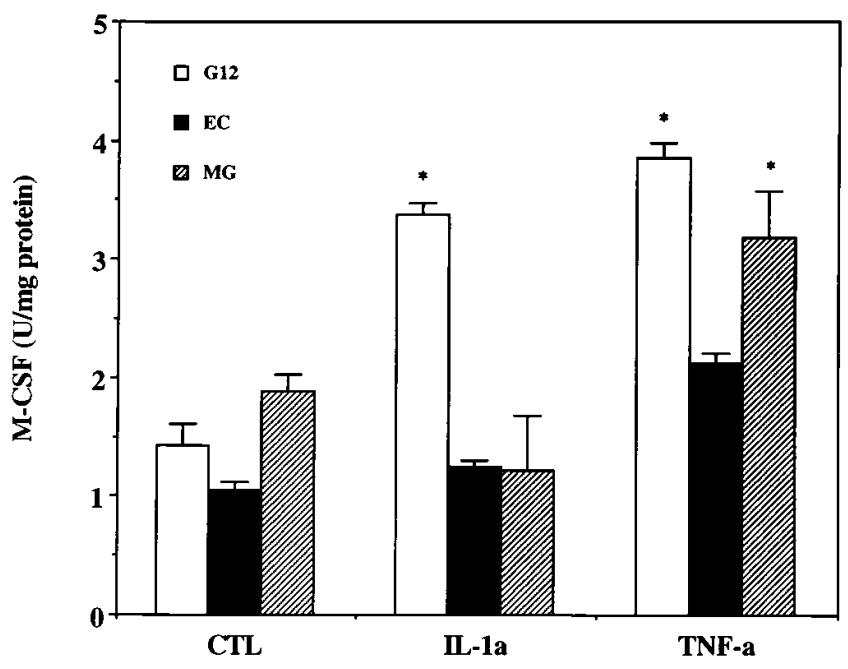

Figure 4. The production of macrophage colony-stimulating factor by human primary bone cell cultures. Cells were incubated with the vehicle (CTL), or IL-1 $\alpha(1 \mathrm{ng} / \mathrm{ml})$, or TNF- $\alpha(2 \mathrm{ng} / \mathrm{ml})$ for $72 \mathrm{~h}$. M-CSF was measured by an ELISA assay on aliquots of the cell supernatants. ELISA assays were done in triplicate for six dishes per condition and the results are the mean \pm SEM. Osteopetrotic primary bone cell cultures both failed to respond to IL- $1 \alpha$ while the response to TNF- $\alpha$ was mixed. Normal cells produced a 2.5- and 3-fold increase in response to IL- $1 \alpha$ and TNF- $\alpha$, respectively. $* P<0.001$ vs. respective control of each patient.

Production of macrophage colony-stimulating factor. IL-1 $\alpha$ and TNF- $\alpha$ are potent stimulators of bone resorption, and enhance the release of M-CSF by osteoblasts $(22,23)$. Indeed, primary osteoblast-like cells produced M-CSF, and basal levels of $\mathrm{M}-\mathrm{CSF}$ in osteopetrotic cell cultures were not significantly differ-

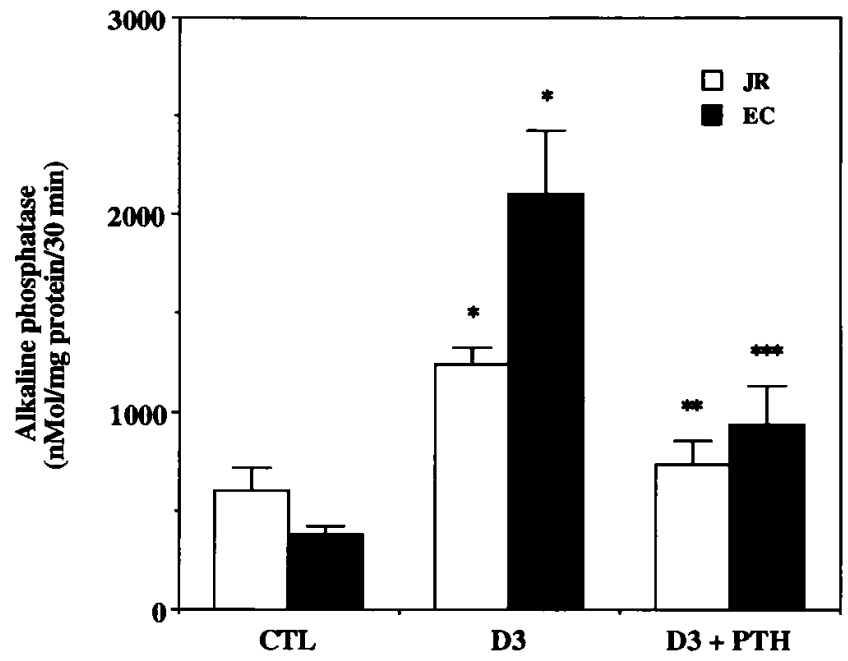

Figure 5. Production of cellular alkaline phosphatase by human primary bone cell cultures from the bone biopsy of EC at the $2 \mathrm{yr}$ follow-up exams, and from JR. Primary cells were again treated with $1,25(\mathrm{OH})_{2} \mathrm{D}_{3}(100 \mathrm{nM})$ for $48 \mathrm{~h}$ and alkaline phosphatase determined on quadriplicate dishes. The cells were also treated in parallel with or without PTH $(100 \mathrm{nM})$. Results are the mean \pm SEM. $* P<0.005$ vs. respective $\mathrm{CTL}, * * P<0.005$ vs. $1,25(\mathrm{OH})_{2} \mathrm{D}_{3}$ treatment for JR, and $* * * P<0.02$ vs. $1,25(\mathrm{OH})_{2} \mathrm{D}_{3}$ treatment for EC. 
ent than controls (Fig. 4). In contrast, the response to IL-1 $\alpha$ was almost absent in both osteopetrotic cell cultures $(P<0.001$ vs. normal cells), whereas TNF- $\alpha$ slightly increased M-CSF production in both osteopetrotic cell cultures. However, they never reached the values obtained with normal cells for $\operatorname{EC~}(P<0.001)$ (Fig. 4).

Follow-up after 2 yr post-transplant. The alkaline phosphatase activity of primary bone cells obtained from a bone biopsy $2 \mathrm{yr}$ post-BMT was normalized. First, the $1,25(\mathrm{OH})_{2} \mathrm{D}_{3^{-}}$ induction was slightly improved as compared to the activity from pre-BMT osteopetrotic cells (4-fold vs. 1.5- to 2-fold).

Second, the $1,25(\mathrm{OH})_{2} \mathrm{D}_{3}$-induced alkaline phosphatase production was reduced in the presence of PTH (100 nM, Fig. 5), unlike in the first bone cell cultures from this osteopetrotic patient (not shown). Primary osteoblast-like cells from a normal, older patient (JR), showed a similar increase in alkaline phosphatase activity in response to $1,25(\mathrm{OH})_{2} \mathrm{D}_{3}$ (2.2-fold increase), and an inhibition of $1,25(\mathrm{OH})_{2} \mathrm{D}_{3}$ induction of about $50 \%$ in response to $\mathrm{PTH}$ (Fig. 5 ).

The $1,25(\mathrm{OH})_{2} \mathrm{D}_{3}$-induced $(100 \mathrm{nM})$ secretion of osteocalcin in these post-BMT osteoblast-like cells was $134.42 \pm 10.69$ $\mathrm{ng} / \mathrm{mg}$ protein $/ 48 \mathrm{~h}$ (eightfold stimulation over basal levels, $P<0.005$, Fig. 6), and is comparable to the secretion by normal cells under similar conditions (Fig. 2, 121.8 $\pm 5.1 \mathrm{ng} / \mathrm{mg}$ protein $/ 48 \mathrm{~h}, \mathrm{NS})$. Parathyroid hormone treatment of these cells also resulted in a significant inhibition of $1,25(\mathrm{OH})_{2} \mathrm{D}_{3}$ induced osteocalcin secretion $(P<0.05$, Fig. 6$)$, a feature also observed in normal cells (25). Human primary osteopetrotic bone cells prepared post-BMT also produced M-CSF in response to both IL-1 $\alpha$ and TNF- $\alpha$. The cells produced 2.08土 0.28 and $3.8 \pm 0.32 \mathrm{U} \mathrm{M}-\mathrm{CSF} / \mathrm{mg}$ protein/72 $\mathrm{h}$ in response to IL- $1 \alpha$ and TNF- $\alpha$, respectively $(P<0.02$ and $P<0.001$ vs. controls, Fig. 7). Thus, the production of M-CSF in response to $\mathrm{TNF}-\alpha$ was normalized $(3.85 \pm 0.13 \mathrm{U} / \mathrm{mg}$ protein $/ 72 \mathrm{~h}$ in nor-

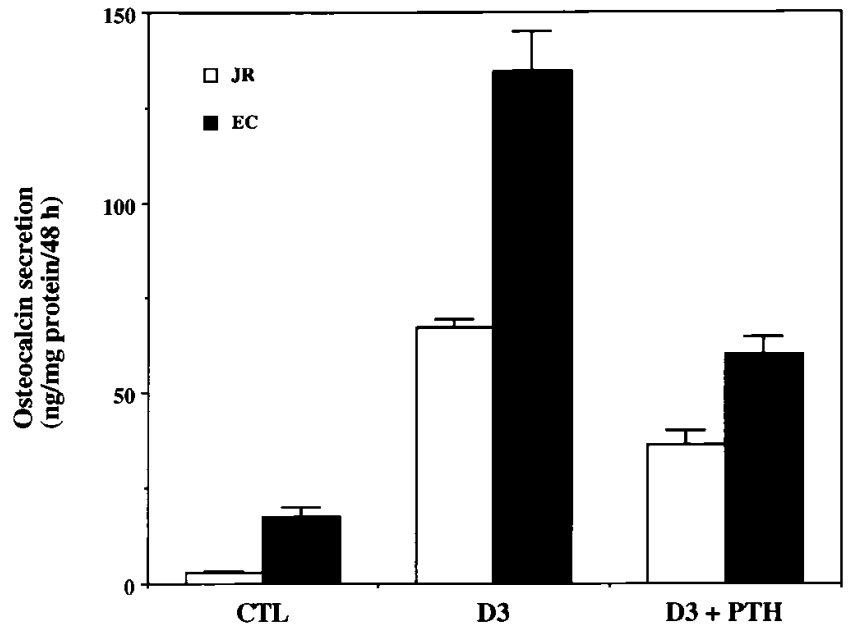

Figure 6. Osteocalcin production by human primary bone cell cultures from the biopsy of EC at the 2-yr follow-up exams. The conditions were as in Fig. 4. Osteocalcin secretion was determined on the cell culture media of these cells after $48 \mathrm{~h}$ of culture. Results are the mean \pm SEM of quadruplicate dishes. Osteocalcin secretion was increased about eight-fold in the presence of $100 \mathrm{nM} 1,25(\mathrm{OH})_{2} \mathrm{D}_{3}$ alone $(P<0.005)$, while PTH inhibited partly $(-50 \%)$ the effect of $1,25(\mathrm{OH})_{2} \mathrm{D}_{3}(P<0.05)$ in these bone cell cultures. The response to both hormones was similar but lower in a cell culture from a normal individual (JR). mal cells, NS) whereas the response to IL- $1 \alpha$ was increased, yet did not reach the production observed in normal cells ( $2.08 \pm 0.28$ vs. $3.37 \pm 0.11, P<0.005)$.

$X$-linked clonality analysis at the HUMARA locus. Allelic ratio of the buccal cells sample, which served as somatic control, was 1.14 excluding extreme Lyonization in this female. The peripheral blood sample obtained $2 \mathrm{yr}$ after BMT was also compatible with polyclonal derivation of cells with an allelic ratio of 1.44. The two X-linked alleles in this post-BMT sample were different than that of the recipient, further confirming the full engraftment of donor cells post-BMT (Fig. 8). The allelic ratio of the osteoblast-like cells pre-BMT was 1.06 , close to the ratio of the buccal cells, and compatible with polyclonal derivation of cells. However, the post-BMT osteoblast cell population gave a significantly shifted allelic ratio that jumped from 1.06 to 2.01. This demonstrates that the osteoblast cells are derived from a limited number of progenitors post-BMT, i.e., the osteoblast cell population has reconstituted oligoclonally post-BMT.

\section{Discussion}

BMT corrected the clinical and bone histological parameters of two osteopetrotic infants. The correction of clinical parameters (plasma alkaline phosphatase, calcium, $1,25(\mathrm{OH})_{2} \mathrm{D}_{3}$, and osteocalcin) appeared soon after BMT (within $3 \mathrm{mo}$ ), indicating that both bone resorption and bone formation indices were corrected. Seric osteocalcin, an index of bone formation/turnover, which was very low in one patient before BMT, was increased after the intervention, a noteworthy discovery. Moreover, the present study suggests that, in addition to a possible osteoclast defect in these patients, osteoblasts were defective. Indeed, both seric parameters and in vitro functional analysis

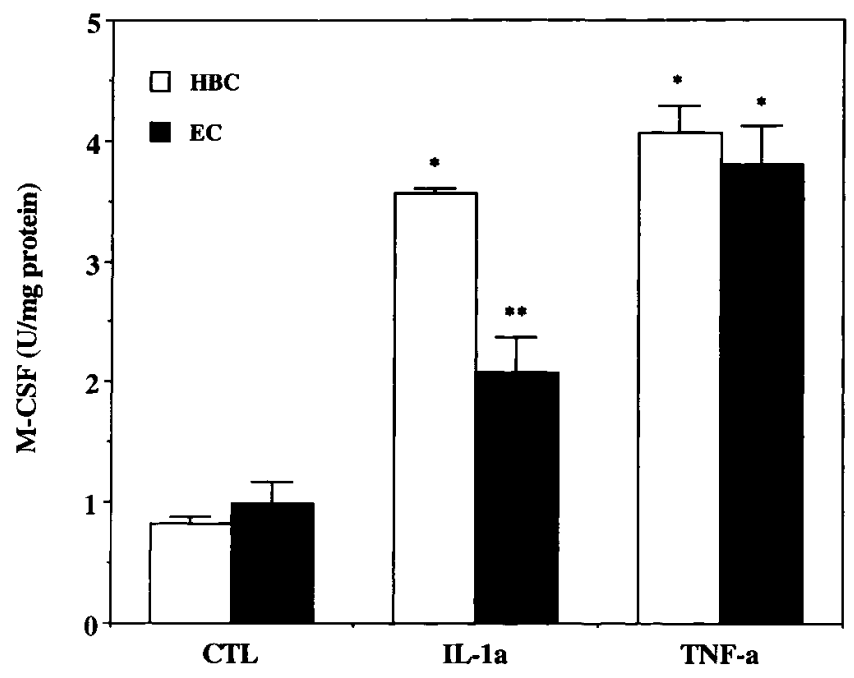

Figure 7. Production of macrophage colony-stimulating factor by human primary bone cell cultures from bone biopsies of the osteopetrotic patient (EC) at the 2-yr follow-up exams. Cells were incubated in the presence of the vehicle (CTL), or IL- $1 \alpha$, or TNF- $\alpha$. M-CSF was determined by an ELISA assay on aliquots of the supernatant. Assays were done in triplicate for four dishes per conditions. Results are the mean \pm SEM. $* P<0.001$ vs. respective control, ${ }^{*} P P<0.02$ vs. respective control. 


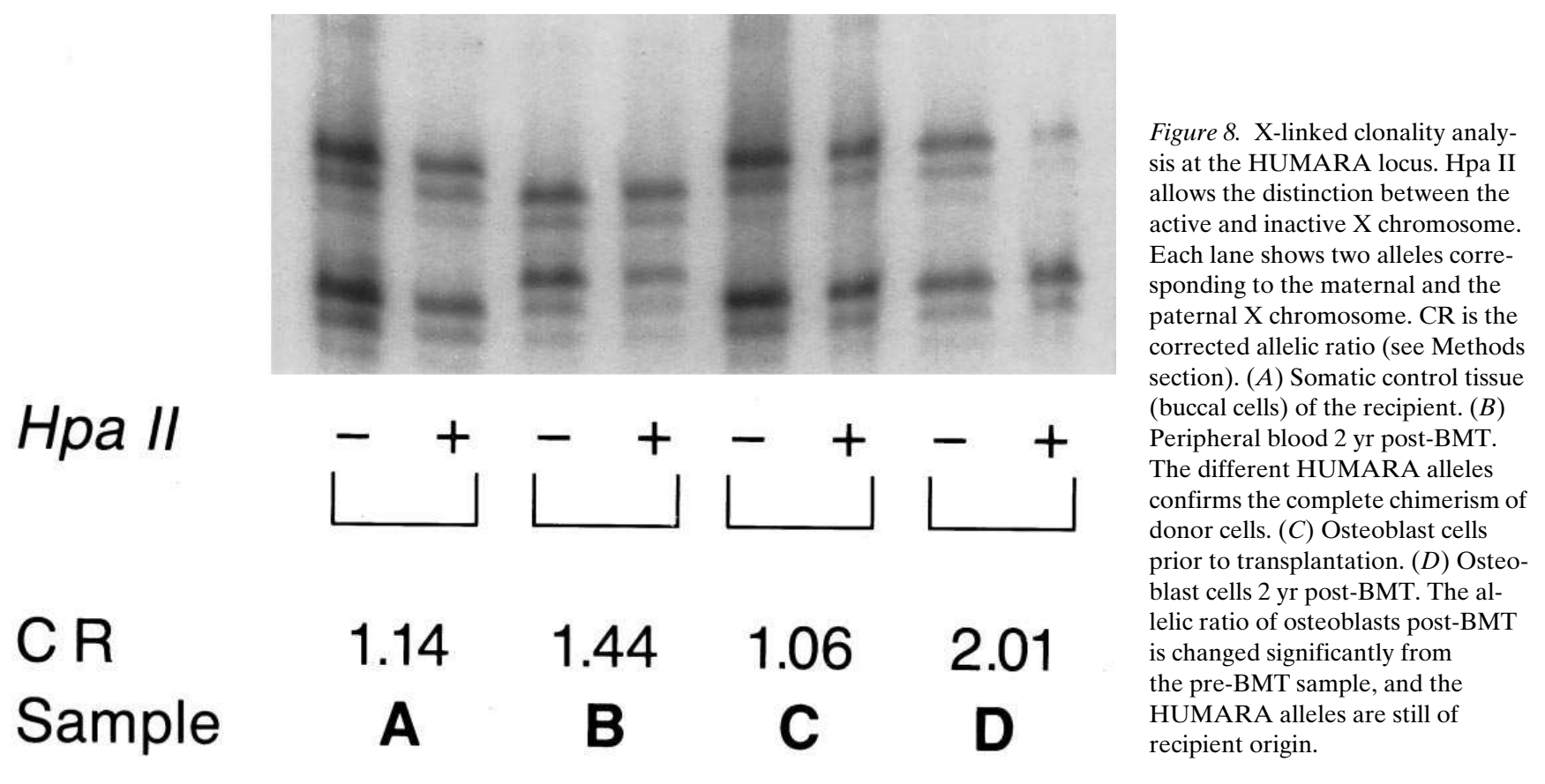

of primary osteoblasts indicate an abnormal behavior for these cells prior to BMT.

Total BMT, such as performed in our unit, could have replaced, in addition to osteoclast precursors, progenitor cells for osteoblasts which can contribute to the de novo release of osteocalcin. A marrow stromal rather than hematopoietic origin of osteoblasts is supported by the induction of chondrogenesis and osteogenesis of bone marrow fragment or cell suspensions transplanted in vivo within diffusion chambers (30), by sequential histological examinations (31), and because bone marrow primary cultures can give rise to osteogenic, osteoblast-like stromal cell cultures $(32,33)$, and cell lines (34). Histological and functional evidence in animal models suggest that osteoblasts can be defective in this disease. In particular, the ultrastructural examination of osteopetrotic rabbit bone revealed abnormalities in both osteoclast and osteoblast populations (35), a finding corroborated by quantitative evaluation of in vivo bone collagen synthesis in rabbit osteopetrotic mutants (36). The metatarsal coculture system of the mutant rabbit skeleton is unable to support the differentiation and function of osteoclasts from normal precursors (37), which again supports the hypothesis of a primary osteoblast defect. However, the hypothesis that BMT also contributed stromal stem cells that could give rise to functional osteoblasts in the osteopetrotic patient must be rejected following the demonstration that osteoblasts obtained $2 \mathrm{yr}$ post-BMT are not of donor origin. The genotype analysis clearly demonstrated the recipient origin.

The aberrant expression of biomarkers of osteoblast-like cells in primary human osteopetrotic bone cell cultures preBMT then becomes puzzling. A resistance to $1,25(\mathrm{OH})_{2} \mathrm{D}_{3}$ or a reduction in the number of vitamin $\mathrm{D}_{3}$ receptors in these pre-BMT cells is very unlikely. This hormonal treatment stimulated alkaline phosphatase activity in osteopetrotic bone cells yet it failed to stimulate osteocalcin release, thus arguing against a generalized disfunction of $1,25(\mathrm{OH})_{2} \mathrm{D}_{3}$ hormonereceptor coupling in this disease. Cournot et al. recently

demonstrated that osteopetrotic infants show variable seric $1,25(\mathrm{OH})_{2} \mathrm{D}_{3}$ levels, regardless of the severity of the disease or the number of functional osteoclasts (2), and the same group also showed that cultured circulating mononuclear cells from osteopetrotic children can still generate multinucleated, osteoclast-like cells in response to $1,25(\mathrm{OH})_{2} \mathrm{D}_{3}(38)$.

The production of alkaline phosphatase was much higher in osteopetrotic cells than in normal cells, as expected from their high seric alkaline phosphatase levels mainly contributed from bone, a situation also attributable in part to the age difference between these patients. In contrast, seric osteocalcin levels were different for the two patients, although both failed to produce significant levels of osteocalcin in vitro regardless of $1,25(\mathrm{OH})_{2} \mathrm{D}_{3}$ treatments. Reduced bone osteocalcin has been observed in op/op and tl/tl rat models, yet these decreases in bone coexisted with elevated serum levels of osteocalcin (16). Hence, this is in contrast to results in one human case (EC) where we observed both a reduction in serum levels and in in vitro bone cell production, but resembles the second case (MG). Abnormal expression of this and other extracellular matrix protein genes have been observed by Marks et al. (14) and Shalhoub et al. (15) in bone from op/op and tl/tl rats, also providing biochemical and molecular evidence of matrix aberrations. However, despite the in vivo normalization of the expression of these genes following CSF-1 (M-CSF) treatment in $\mathrm{tl} / \mathrm{tl}$ rats, the disease still persists as regional sclerosis (39).

Osteopetrotic cells produced similar basal M-CSF levels as normal cells, however, because the response to IL- $1 \alpha$ and TNF- $\alpha$ was different in our osteopetrotic primary osteoblastlike cells as compared to normal cells, or other osteoblast-like cells $(22,23)$, the failure to respond normally to both cytokines may reflect the state of differentiation of these cells (as does the alkaline phosphatase activity and osteocalcin release observed in these cells), which failed to express either the necessary receptors for IL- $1 \alpha$ or TNF- $\alpha$ pre-BMT, or expressed a postreceptor defect. A truncated, biologically inactive molecule of M-CSF may be responsible for this condition in the os- 
teopetrotic (op) mouse $(24,40)$. This hypothesis is unlikely in our study because the normal production of M-CSF 2 yr postBMT in EC argues against a primary M-CSF defect in this case, and STR gene typing provided evidence that osteoblasts were not replaced by bone marrow transplantation. The normalization of all tested in vitro parameters $2 \mathrm{yr}$ post-BMT in EC also suggests that the osteoblast cell defect(s) previously observed in this patient was corrected. It could also suggest that an abnormal cell present in the bone biopsy may have had a growth advantage over normal cells in primary culture.

However, clonality analysis at the HUMARA locus has confirmed that osteoblast cells are polyclonally derived preBMT. The polyclonal finding pre-BMT indicates that osteoblasts in osteopetrosis are not derived from a single mutant cell with a growth advantage such as seen in human neoplastic disease. This rather suggests a germ line defect or a field effect which in this case would be an abnormal microenvironment. Moreover, polyclonality indicates that the culture process did not select for any particular progenitor cells which could have a different phenotype from the original cells. The oligoclonal reconstitution post-BMT is interesting. It is possible that the pool of stem cells giving rise to osteoblasts was considerably reduced by the effect of the chemotherapy and that the entire osteoblast population reconstituted from only a few viable progenitors. However, the correction of the abnormal phenotype post-BMT raises the possibility that the chemotherapy has selected osteoblasts with a normal phenotype, or else that the change in the microenvironment after BMT has selected for a subpopulation of osteoblasts responding appropriately to the signals of the milieu (osteoclast-derived signals?). In a previous study, transplanted osteoclasts, but not osteoblasts, were shown to be of donor origin in one affected infant (10), as corroborated by the present study. This all raises a fundamental question: What induced the differentiation of osteoblasts in this osteopetrotic infant following BMT if precursor cells for osteoblasts were not replaced with those from the donor? The most simple and direct way would be to hypothesize that BMT, by replacing osteoclast precursor cells, and hence osteoclasts, provided a favorable microenvironment to trigger the differentiation of osteoblasts. Conversely, BMT may have helped reduce the proliferation of non-differentiated osteoblasts, hence favoring the proliferation of a few number of differentiated osteoblasts and/or their progenitors. This last hypothesis would then agree with the oligoclonal derivation of these cells post-BMT. It also suggests that a functional crosstalk may be taking place between osteoblasts and osteoclasts to regulate bone mineralization/remodeling, and that this signaling pathway is defective in osteopetrosis. Indeed, co-cultures of $\mathrm{tl} / \mathrm{tl}$ rat osteoblasts and normal osteoclasts failed to trigger resorption (pit formation), despite $1,25(\mathrm{OH})_{2} \mathrm{D}_{3}$ treatments, in contrast to the situation with normal osteoblasts (41), indicating that a functional cross-talk between osteoblasts and osteoclasts is disrupted in these animals. Hence, the etiology of this dysfunction is most likely multigenic, but our results underline the essential role of osteoblasts in this human disease which could also stem from an aberrant cross-talk between abnormal osteoclasts and osteoblasts.

\section{Acknowledgments}

We thank Dr. Patrice Poubelle from the Centre Hospitalier de l'Université Laval for helpful discussion on the measures of cytokines and in particular for M-CSF. We acknowledge the generous gift of $1,25(\mathrm{OH})_{2} \mathrm{D}_{3}$ by Dr. Uskokovic of Hoffman-La Roche, Nutley, NJ. We also thank the personnel of the Biochemistry Department of our hospital for their enthusiastic contribution to the measures of the clinical parameters. We thank Mrs. Johanne Matioli and Sylvie Provost for excellent technical assistance during the course of these studies.

This work was supported by a grant to D. Lajeunesse from the Kidney Foundation of Canada. D. Lajeunesse and L. Busque are scholars of the Fonds de la Recherche en Santé du Québec (FRSQ).

\section{References}

1. Marks, S.C. Jr., and J.L. McGuire. 1989. Primary bone cell disfunction. II. Osteopetrosis. In Metabolic Bone Disease: Cellular and Tissue Mechanisms. C. Tam, J. Heersche, T. Murray, editors. CRC Press, Boca Raton, FL. 49-61.

2. Cournot, G., C.L. Trubert-Thil, M. Petrovic, A. Boyle, C. Cormier, D. Girault, A. Fischer, and M. Garabedian. 1992. Mineral metabolism in infants with malignant osteopetrosis: Heterogeneity in plasma 1,25-dihydroxyvitamin D levels and bone histology. J. Bone. Miner. Res. 7:1-10.

3. Sly, W.S., D. Hewett-Emmett, M.P. Whyte, Y.S. Yu, and R.E. Tashian. 1983. Carbonic anhydrase II deficiency identified as the primary defect in the autosomal recessive syndrome of osteopetrosis with renal tubular acidosis and cerebral calcification. Proc. Natl. Acad. Sci. USA. 80:2752-2756.

4. Fisher, A., C. Griscelli, W. Friedrich, B. Kubanek, R. Levinsky, G. Morgan, J. Vossen, and G. Wagemaker. 1986. Bone marrow transplantation for immunodeficiencies and osteopetrosis: European survey 1968-1985. Lancet. 2: 1080-1083.

5. Fischer, A. 1989. Bone marrow transplantation in immunodeficiency and osteopetrosis. Bone Marrow Transplant. 4:12-14.

6. Walker, D.G. 1975. Bone resorption restored in osteopetrotic mice by transplants of normal bone marrow and spleen cells. Science (Wash. DC). 190: 784-785.

7. Milhaud, G., M.L. Labat, B. Graf, M. Juster, N. Balmain, R. Moutier, and K. Toyama. 1975. Démonstration cinétique, radiographique et histologique de la guérison de l'ostéopétrose congénitale du rat. C R Acad. Sci. [D] 280:24852488.

8. Zerwekh, J.E., S.C. Marks Jr., and J.L. McGuire. 1987. Elevated serum 1,25-dihydroxyvitamin $\mathrm{D}$ in osteopetrotic mutations in three species. Bone Miner. 2:193-199.

9. Key, L., D. Carnes, S. Cole, M. Holtrop, Z. Bar-Shavit, F. Shapiro, R. Arceci, J. Steinberg, C. Gundberg, A. Kahn et al. 1984. Treatment of congenital osteopetrosis with high-dose calcitriol. N. Engl. J. Med. 310:409-415.

10. Coccia, P.F., W. Krivitt, J. Cervenka, C. Clawson, J.H. Kersey, T. Kim, M.E. Nesbit, N.K.C. Ramsay, P.I. Warkentin, S.L. Teitelbaum et al. 1980. Successful bone-marrow transplantation for infantile malignant osteopetrosis. $N$. Engl. J. Med. 302:701-708.

11. Reeves, J., S. Arnaud, S. Gordon, B. Subryan, M. Block, W. Huffer, C. Arnaud, G. Mundy, and M. Haussler. 1981. The pathogenesis of infantile malignant osteopetrosis: Bone mineral metabolism and complications in five infants. Metab. Bone Dis. Relat. Res. 3:135-142.

12. Sieff, C.A., J.M. Chessells, R.J. Levinsky, J. Pritchard, D.W. Rogers, A Casey, K. Muller, and C.M. Hall. 1983. Allogeneic bone-marrow transplantation in infantile malignant osteopetrosis. Lancet. 1:437-441.

13. Kaplan, F.S., C.S. August, M.D. Fallon, M. Dalinka, L. Axel and J.G. Haddad. 1988. Successful treatment of infantile malignant osteopetrosis by bone marrow transplantation. J. Bone Jt. Surg. Am. 70A:617-623.

14. Marks, S.C. Jr., S. Mackowiak, V. Shaloub, J.B. Lian, and G.S. Stein. 1989. Proliferation and differentiation of osteoblasts in osteopetrotic rats: Modification in expression of genes encoding cell growth and extracellular matrix proteins. Connect. Tissue Res. 21:107-116.

15. Shalhoub, V., M.E. Jackson, J.E. Lian, G.S. Stein, and S.C. Marks, Jr. 1991. Gene expression during skeletal development in three osteopetrotic rat mutations. J. Biol. Chem. 266:9847-9856.

16. Lian, J.B., and S.C. Marks, Jr. 1990. Osteopetrosis in the rat: Coexistence of reductions in osteocalcin and bone resorption. Endocrinology. 126:955-962.

17. Braidman, I.P., and D.C. Anderson. 1993. Role of bone matrix in osteoclast recruitment in cultured fetal rat calvariae. J. Bone Miner. Res. 8:231-238.

18. Marks, S.C., M.F. Seifert, and J.L. McGuire. 1984. Congenitally osteopetrotic (op/op) mice are not cured by transplants of spleen or bone marrow cells from normal littermates. Metab. Bone Dis. Relat. Res. 5:183-186.

19. Wiktor-Jedrzejczak, W., A. Ahmed, C. Szczylik, and R.R. Skelly. 1982. Hematological characterization of congenital osteopetrosis in op/op mouse. Possible mechanism for abnormal macrophage differentiation. J. Exp. Med. 156:1516-1527.

20. Stanley, E.R. 1986. Action of the colony-stimulating factor, CSF-1. In Biochemistry of Macrophages. Ciba Foundation Symposium 118. J. Wiley \& Sons, Inc. New York. 29-41.

21. Elford, P.R., R. Felix, M. Cecchini, U. Trechsel, and H. Fleisch. 1987. Murine osteoblastlike cells and the osteogenic cell MC3T3-E1 release a mac- 
rophage colony-stimulating activity in culture. Calcif. Tissue Int. 41:151-156.

22. Sato, K., K. Kasono, Y. Fujii, M. Kawakami, T. Tsushima, and K. Shizume. 1987. Tumor necrosis factor type a (cachectin) stimulates mouse osteoblast-like cells (MC3T3-E1) to produce macrophage-colony stimulating activity and prostaglandin $\mathrm{E}_{2}$. Biochem. Biophys. Res. Commun. 145:323-329.

23. Sato, K., Y. Fujii, S. Asano, T. Ohtusuki, M. Kawakami, K. Kasono, T. Tsushima, and K. Shizume. 1986. Recombinant human interleukin 1 alpha and beta stimulate mouse osteoblast-like cells (MC3T3-E1) to produce macrophagecolony stimulating activity and prostaglandin $\mathrm{E}_{2}$. Biochem. Biophys. Res. Commun. 141:285-291.

24. Felix, R., M.G. Cecchini, W. Hofstetter, P.R. Elford, A. Stutzer, and H. Fleisch. 1990. Impairment of macrophage colony-stimulating factor production and lack of resident bone marrow macrophages in the osteopetrotic op/op mouse. J. Bone Miner. Res. 5:781-789.

25. Lajeunesse, D., G.M. Kiebzak, C. Frondoza, and B. Sacktor. 1991. Regulation of osteocalcin secretion by human primary bone cells and by the human osteosarcoma cell line MG-63. Bone Miner. 14:237-250.

26. Allen, R.C., H.Y. Zoghbi, A.B. Moseley, H.M. Rosenblatt, and J.W. Belmont. 1992. Methylation of HpaII and HhaI sites near the polymorphic $\mathrm{CAG}$ repeat in the human androgen-receptor gene correlates with $\mathrm{X}$ chromosome inactivation. Am. J. Hum. Genet. 51:1229-1232.

27. Willman, C.L., L. Busque, B.B. Griffith, B.E. Favara, K.L. McClain, M.H. Duncan, and D.G. Gilliland. 1994. Langerhans'-cell histiocytosis (Histiocytosis X)-A clonal proliferative disease. N. Engl. J. Med. 331:154

28. Lajeunesse, D., C. Frondoza, B. Schoffield, and B. Sacktor. 1990. Osteocalcin secretion by the human osteosarcoma cell line MG-63. J. Bone Miner. Res. 5:915-922.

29. Lowry, O.H., N.J. Rosebrough, A.L. Farr, and R.J. Randall. 1951. Protein measurement with the Folin phenol reagent. J. Biol. Chem. 193:265-275.

30. Ashton, B.A., T.D. Allen, C.R. Howlett, C.C. Eagleson, A. Hattori, and M.E. Owen. 1980. Formation of bone and cartilage by marrow stromal cells in diffusion chambers in vivo. Clin. Orthop. Relat. Res. 151:294-299.

31. Bab, I., B.A. Ashton, D. Gazit, G. Marx, M.C. Williamson, and M.E. Owen. 1986. Kinetics and differentiation of marrow stromal cells in diffusion chambers in vivo. J. Cell. Sci. 84:139-144.

32. Luria, E.A., M.E. Owen, A.J. Friedenstein, J.F. Morris, and S.A. Kuznetsow. 1987. Bone formation in organ cultures of bone marrow. Cell Tiss. Res. 248:449-455.

33. Mardon, H.J., J. Bee, K. Mark, and M.E. Owen. 1987. Development of osteogenic tissue in diffusion chambers from early precursor cells in bone marrow of adult rats. Cell. Tissue Res. 250:157-164.

34. Benagahu, D., Y. Kletter, D. Zipori, and S. Wientroub. 1989. Bone marrow-derived stromal cell line expressing osteoblastic phenotype in vitro and osteogenic capacity in vivo. J. Cell. Physiol. 140:1-6.

35. Marks, S.C., Jr., C.A. MacKay, and M.F. Seifert. 1987. The osteopetrotic rabbit: Skeletal cytology and ultrastructure. Am. J. Anat. 178:300-307.

36. Popoff, S.N., and S.C. Marks, Jr. 1990. The relationships of abnormalities in dental and skeletal development in the osteopetrotic rabbit. J. Oral Pathol. Med. 19:5-12.

37. Lenhard, S., S.N. Popoff, and S.C. Marks, Jr. 1990. Defective osteoclast differentiation and function in the osteopetrotic (os) rabbit. Am. J. Anat. 188 $438-444$.

38. Cournot, G., M. Petrovic, C.-L. Trubert, C. Cormier, D. Girault, A. Fischer, and M. Garabedian. 1993. Cultured circulating mononuclear cells from osteopetrotic infants express the osteoclast-associated vitronectin receptor and form mutinucleated cells in response to 1,25-dihydroxyvitamin $\mathrm{D}_{3}$. J. Bone Miner. Res. 8:61-70.

39. Wisner-Lynch, L.S., V. Shalhoub, and S.C. Marks, Jr. 1995. Administration of colony-stimulating factor-1 to toothless osteopetrotic rats normalizes osteoblast, but not osteoclast, gene expression. Bone 16:611-618.

40. Yoshida, H., S.I. Hayashi, T. Kunisada, M. Ogowa, S. Nishikawa, H. Okamura, T. Sudo, L.D. Schultz, and S. Nishikawa. 1990. The murine mutation osteopetrosis is in the coding region of the macrophage colony-stimulating factor gene. Nature (Lond.). 345:442-444

41. Sundquist, K.T., M.E. Jackson, D.C. Hermey, and S.C. Marks Jr. 1995 Osteoblasts from the toothless (osteopetrotic) mutation in rat are unable to direct bone resorption by normal osteoclasts in response to 1,25 -dihydroxyvitamin D. Tissue Cell. 27:569-574. 